Maria AgNieszKa SroczyŃSKA

Cardinal Stefan Wyszyński University

\title{
AXIOLOGICAL PREFERENCES OF POLISH YOUTH IN THE CONTEXT OF SOCIAL TRANSFORMATION AND POST- TRANSFORMATION
}

\begin{abstract}
The paper analyzes axiological preferences of Polish youth over the last 30 years in a comparative context. The presented review refers to quantitative sociological research. The analysis starts with the period of systemic transformation with a deep "cultural rupture" visible in the conflict of values related to ideology, politics and economy. Young people of that time often had a feeling of "generational abandonment", uncertainty and confusion. On the other hand, the post-transformation period, symbolically initiated by Poland's accession to the European Union, brought a shift towards pragmatic and ethos-centered orientations. A prolonged process of becoming an adult is accompanied by moratorivity. Post-transformation, however, means significant identity-related and social changes, which largely corresponds to the development of human capital, manifested in the field of skills, intuition and creative potential. Nevertheless, it should be remembered that predicting future changes in the values of Polish society, especially young people, carries a considerable risk of unverifiability.
\end{abstract}

KeYwORDs: Polish youth, axiological preferences, continuity and change, transformation period, post-transformation period 


\section{INTRODUCTION}

Today, sociology and its sub-disciplines face serious challenges related to changes in the nature of social life at all its levels. Not surprisingly, most empiricists abandon the hitherto important predictive function in favor of cautious, fragmented and short-term forecasts. But also sociologists opting for theoretical inquiry are abandoning visions, such as those presented by Francis Fukuyama (2006). The end of history, announcing the universal victory of liberal democracy, is somewhat not to be seen. On the contrary - various forms of populism are becoming more and more conspicuous, focussing on threatened security, growing social inequalities or identity problems (Beck, Giddens, Lash, 1994). How do young people find themselves in this situation, what is their future in the world whose foundations are uncertain as never before? The perception of social matters is shaped by the media hyper-reality, which has become a challenge for what is direct and tangible. On the other hand, our coexistence in the public space is connected with the need to warm up and suspend everyday identities (Maffesoli, 2008: 107-115). The phenomena taking the form of events or mega-ceremonies represent a combination of collective behaviour with a consummerism orientation strengthened by marketing activities, and at the same time - highly individualized (com. Such-Pyrgiel, 2012).

Zygmunt Bauman, a keen analyst of the modern consumer society, suggests that new forms of coexistence are now becoming an ersatz, no longer able to revive the spirit of the "dead" community. Postmodern fears, on the other hand, are not diminishing but are merely being redistributed. They include: uncertainty, insecurity, a sense of personal threat, atrophy of bonds and weakening of solidarity, and sometimes also the feeling of meaninglessness of one's activities (Bauman, 2006). These phenomena are reinforced by biological and social consequences of the COVID-19 pandemic - recently remaining the most serious global challenge for young generations. Moreover, what is associated with postmodernity has the characteristics of periods of transition or disintegration rather than of the new organization of social life. Nowadays, we are facing a progressive, even though not fully realized, process of abandoning normative, institutionally defined content. That is accompanied by growing relativistic tendencies based on the criteria of conscience and individual autonomy (Bauman, 2013). 
Despite these difficulties, all activities undertaken by people (especially young ones) in order to provide and/or create a framework for the existence-shared-with-others are remaining a valuable, even indispensable condition for every form of community, and consequently also for their own subjectivity. They are based on axiological orientations, which in the case of adolescents have more permanent components related to primary socialization, as well as more fluid ones resulting from the influence of peer groups, new media, and also educational and market institutions. It is therefore worthwhile to look at the sphere of values that young Poles give preference to, considering tendencies noticeable from the perspective of social transformation and post-transformation. The latter is associated with the accession to the European Union and openness to postmodernity. The goals articulated by young people and activities connected with them (those related to the pragmatic orientation as well as the ethos-centered ones) can act as both driving and restraining forces in the social development, which is associated with a change in the role of the young generation on the political level (Szafraniec, 2012, pp. 101-122).

\section{Methodological isSUES}

The article reviews matters corresponding with research issues studied within sociological sciences.

They concern both the states of affairs valued by young people, described in large numbers by representatives of this discipline, and the results of Author's own empirical research conducted over the decade among students of the last grades of secondary schools in the Swiętokrzyskie region (Sroczyńska, 2013; 2020). Research problems include both preferences in terms of youth values, continuity and changes in the way choices are made, and methodological issues related to the methods of researching them. The Author's intention is to present an outline of the above subject matter, arousing interest in the issues of both professional scholars and those concerned about the situation of the young generation of Poles and their participation in social life. The study involved the application of the analysis of the existing content, selected in accordance with the subject of the study. 
The themes were presented in a synthetic context, both on the basis of the discussed concepts and empirical studies.

At the beginning the paper inquires what has a superior value (axionormative systems) in a given culture, what belongs to the interpretative system that gives order to the reality and becomes internalized in the dimension of individual personalities. Values occur either in a hierarchical (superiority - inferiority) relations or in a horizontal (ex aequo) order - as desirable commodities that nevertheless come to the fore "only now and again" in a routinized everyday life. Values represent states of affairs that give individuals and societies meaning and identification, motivation and legitimacy. Values are classified in several ways and concretized in the form of indicators, which, in empirical studies, may reflect individual, more autonomous groups of values or have a holistic nature. In the social reality, we encounter many different types of values, e.g. personal and social, autotelic and instrumental, ultimate, everyday and fundamental, materialistic and post-materialistic, related to dignity and pragmatic, particularistic and universal, democratic and liberal, traditional and modern (Mariański, 2018, p. .315-323). Individual categories of values are not disjoint and typically coexist on the empirical level available to sociological cognition. The declared values do not always overlap with the recognized and practiced ones, and the modern axiological "market" largely affects individual decisions made by participants of social life (Mariański, 2015, pp. 877-882).

The empirical examplifications presented in the text, by necessity selective and cross-sectional (therefore more quantitative than qualitative), highlight issues that are not fully identified and, at the same time, topical in the context of the discussed issues. An attempt to identify certain trends affecting the process of social transformation and post-transformation is not an easy task, although examining the axiological problems of the youth world has become one of the most popular scientific undertakings among educators, psychologists and sociologists. The most extensive line of research, conducted since the 1970s in the field of youth sociology is devoted to life orientations, educational and professional aspirations, and the value systems of young people. However, it is worth remembering that generalizations and predictions regarding the state of young people and their role in society are burdened with a significant risk of unverifiability (Niezgoda, 2014, pp. 28-32). 


\section{AXIOLOgiCAL ORIENTATIONS OF YOUNG POLES (TRANSFORMATION CONTEXT)}

The surveys undertaken by sociologists before the onset of systemic transformation showed generational similarities as well as changes taking place in the world of values (Nowak, 1989). On the one hand, both parents and growing-up children opted for values of private-stabilization nature, on the other hand, the young believed that the significance of stabilization-oriented attitudes was not so different from achievement-oriented attitudes as their parents did. The young were focused on themselves and small groups to a larger extent than their parents, with pro-social values, especially those cultivated in large groups, being less appreciated. Antoni Sułek remarked that the possible tangible impact on the functioning of small primary groups, as well as a defensive reaction to a hostile world contribute to the fact that "The family, circle of friends, one's own person are becoming sanctuaries in which one can take refuge and in which one can "be oneself" "(Sułek, 1989, p. 372).

Undoubtedly, both in the past and presently, many factors (including: social structure, political context, functioning of state institutions and the labor market, tradition, popular culture and the climate of interpersonal relations) have had a very subtle and often indirect impact on the world of young people's values. In turn, their orientations and activities modify the existing social conditions. The fall of communism in Central and Eastern Europe initiated changes consisting in the transition from a monocentric system, especially in the political and economic sphere, to a post-monocentric one. The latter led to an uncontrolled diversification in various areas of social life, the entry into the sphere of global communication effect, the emergence of new institutions and social roles, as well as opportunities and threats (Gilejko, 2005, pp. 75-91). At the beginning of the 1990s, a great interest was aroused in the hypothesis of Ronald Inglehart (2003, pp. 146-168) of the shift of values from materialistic to post-materialistic along with the generational change. The former values are aimed at stability and a sense of security, the latter are focused on democratic values, individual freedom, autonomy and emancipation. There is no doubt that the youngest cohorts (15-24 years of age) were and are more post-materialistic in their attitudes than adults in general. However, when compared with German 
youth, Polish young people (surveyed in 2001) represented a materialistic orientation twice as often $(31 \%-16 \%)$ as their German peers, and a postmaterialistic one almost three times less often (8\% - 23\%) (Szawiel, 2005, pp. 196-199). Apparently, the effect of culturally shaped meanings and symbols on economic indicators and on the advancement in democracy is stronger than the other way round. The modernization complexities of the state of Polish society are reflected in the " dilemma of three clocks", which highlights the desynchronization of activities in important areas of social life (the reform of the constitutional law was associated with considerably slower and turbulent transformations of the economy and changes in attitudes, values and lifestyle, lasting even as long as generations (Sztompka, 2005, pp. 130-141).

Values are seen as the result of adolescents' immersion in a world that is only partially influenced by traditional, goal-oriented socialization agendas, especially family and school. The amount of content assimilated by young people, without parental or teacher knowledge and control, is constantly growing, putting into question the future of intergenerational relations. Nevertheless, the axiological sphere still plays an important role in the process of cultural transmission, and the change (on the macrostructural scale) is not of abrupt nature. The specificity of time and place is responsible for defining axiological-normative systems that characterize individual age groups, and at the same time remain a manifestation of generational expression. The lack of a clear rebellion phase against the older generation fosters adopting the existing scenarios of viewing and experiencing the world, while its presence is conducive to introducing changes not only in close generations (every 5 - 6 years), but also in a wider social context. Young people on the threshold of adulthood, surveyed in the late 2000s, looked more like an inter-generation, on the one hand becoming similar to their own parents, and on the other hand, to a younger cohort of teenagers. One could notice an "inheritance" of principal patterns of the axionormative order related to personal and affiliate values, and to a lesser extent to values emphasizing identification with a religious or national community. Author's research showed that young people are more "distinct" than their parents, more inclined towards intense experiencing reality, which is individualized but gives a greater sense of freedom (Sroczyńska, 2013). That was accompanied by a higher appreciation of 
education, interesting work, big money, a colorful and interesting life and the feeling of being someone special. It was conducive to building a different way of thinking about oneself and one's place in the world, as well as about a new quality of relations based on community with peers, giving the opportunity to function not only in the reality (neotribes), but first of all in the independent space of the Web.

Interestingly, among the enumerated life goals and aspirations of young people, systematically studied for a quarter of a century by the Centre for Public Opinion Research (CPOR), the following rose in importance: love, friendship (in $1994-39 \%$ of responses, in $2018-52 \%$ ), successful career (respectively: $19 \%-33 \%)$ and a good material position $(25 \%-33 \%)$. On the other hand, analysing the subsequent age groups one can notice that the following aspects decreased in significance: successful family life and children (48\% in 1994, 42\% in 2018), interesting work in line with one's interests (52\% - 40\%), a peaceful life without conflicts $(34 \%-29 \%)$, being useful to others $(15 \%-10 \%)$, living in accordance with one's religious principles $(10 \%-5 \%)$. It should be noted, however, that the increase or decrease in the rank of the above values is not linear (Grabowska, Gwiazda, 2019).

In her research of 2009, conducted on a representative sample of 1111 secondary school leavers from the Świętokrzyskie region, the Author used Scheler Values Scale (SWS). It refers to the hierarchy of Max Scheler's values and permits the ranks of 50 values to be determined in the environment of young people and adults. They are included in six subscales - four basic values: hedonistic, vital, aesthetic, truth, moral and holiness and two factor, vital values - physical fitness and strength as well as endurance and sacred values - secular and religious sacredness. The conducted research revealed the similarity of the generational value profiles of young people and their parents, and a kind of unquestionable imponderables, co-creating collective identities. These include moral values (necessary from the point of view of an individual's relationship with others and with oneself) and a group of sacred values, with a distinguished group of secular values. On the other hand, other axiological categories - vital, aesthetic and truth were more important for the younger than for the older generation (which is undoubtedly influenced by the context of adolescence) (Sroczyńska, 2013, pp. 110-119). 
In the late 2000s Poles (surveyed by CPOR) expected children, when they grew up, to represent attitudes and behaviours indicating a high esteem for the figure of "ethical entrepreneur", distinguished by individualism. The most important ranks were assigned to: moral behavior (64\%), having one's own opinion (59\%), the ability to fight for one's own matters (58\%), showing initiative and entrepreneurship (56\%), setting ambitious life goals (54\%), and the pursuit of one's own happiness (53\%). It was only later that the ideas of interpersonal relations (helping others $-47 \%$ or good cooperation with others $-46 \%)$, being a patriot (44\%) and a good citizen (39\%) appeared. Even less importance, as far as the desired personality traits of young people were concerned, was attached to high income (37\%) and to being a religious person (34\%) (Smak-Wójcicka, 2009). The discussed axiological contexts corresponded to the inconsistency of changes in the economic sphere, fluctuations in the labor market, modifications in the educational sphere, weakening of religiosity and traditional customs. Not all processes were pro-developmental, some of them led to increasing social polarization and a specific confusion of the young generation.

\section{Axiological ORIENTATIONS OF THE YOUTH (POST-TRANSFORMATION CONTEXT)}

The rate and extent of changes taking place in the Polish society in the late 2000s and early 2010s was connected with more or less successful attempts of the state to make up for the "civilization backlog", accompanied by the abandonment by traditional institutions and authorities (parents, teachers, clergy) of their roles as guides and mentors and their replacement by modern instant messaging. This led to the transition of the responsibility for the choices onto the youth, and consequently, resulted in their cultural "drifting" and a weakening of the sense of accountability for the state and national community (Sroczyńska, 2013; 2018). It is still hard to decide whether the possible positive outcomes of promoting creative, independent and innovative attitudes are able to compensate for the negative aspects (disappointment, frustration, passivity, focusing on oneself). Thus, the situation in which young people are 
socialized into the world of consumption is of concern to those who see the importance of "axiological universals" in the process of education.

In generational relations one can observe the phenomenon of tolerant solidarity. On the one hand it is related to the economic and structural coalition in households and the accompanying emotional intimacy, and on the other hand, it means mutual growing apart and, at the same time, accepting increasing differences in the axiological sub-worlds ( Szlendak, 2012: 75-90). Even if the label of " absorbers of stimuli" and opinions that for young people nowadays "nothing matters" or "everything matters" are not to be fully accepted, it is difficult not to notice the progressive hybridization of their personality, which is the result of life in social niches created by peer groups (including internet communities) that filter the content of popular culture. On the one hand, there is a certain generational similarity at the axionormative level, especially as far as the recognized values are concerned, and on the other - it has a discretionary and situational nature, especially in the context of implementation.

Therefore, one cannot speak of a stable axiological "structure" that translates itself into a coherent orientation of the young generation. On the contrary, "there has never been one youth, there are only its varieties" (Wrzesień, 2015:25), and moratorivity is an indispensable feature of this phase of life. Young people still yearn for the presence of adults with whom they can have a dialogue and an argument, disregarding as Somebody Else's Problem (in the practice of invalidating) the ideas they communicate, especially those of a moral nature. This does not prevent the elders from being expected to be "real guardians" (not necessarily authorities or influencers and from making them somewhat responsible for pointing out the right ways of life to the young generation.

The environmental differentiation of adolescents and young adults is sometimes identified with a lifestyle characteristic of neo-tribes and corresponding to the axiological context. The authors of "The World of the Young" report of 2016 (prepared mainly for business purposes) associated the lifestyles of millennials (childless young people aged 16-29) with five categories. The most numerous one is represented by homies (30\%), focused on the local community, social media, peace of mind and the consumption of goods and services, and then goodies (23\%) - appreciating the family, traditional and 
conservative values, voting out of a sense of civic duty, and lifehackers (19\%), mostly men, singles, with a neoliberal economic sense, "who like the feeling of being the first category customers " (Brzozowska-Brywczyńska, 2019, pp. 203-209). The fourth category is represented by regrets ("angry and helpless" $16 \%)$, mainly poorer, working youth and the fifth by hipsters (12\%) from large Polish cities, focusing on their self-development, hobbies and travels. According to the authors of the report, all these "tribes" share a conviction of encountering injustice (87\%), of young people not being granted their due position in history and of the prevalence of lying in public life. The conclusions drawn from the quoted report (although undoubtedly simplified and serving marketing goals) do not convey an optimistic message about the condition of modern youth. At the same time, they are not inconsistent with the considerations about the essentially lonely experience of the prolonged phase of entering adulthood (emerging adulthood), which is devoid of the typical liminality that characterizes traditional rituals of passage. The process of individualization, combined with the belief in opportunities offered by the existing socio-economic order and consumerism, generates a fairly common conviction that life should consist in experiencing pleasures and happiness. Young Poles can be increasingly attributed with an orientation towards the realization of the model of a comfortable existence, without problems and conflicts, not involved in the lives of other people or in self-development, and at the same time appreciating the value of good communication and proximity of other people.

These trends are confirmed by the detailed results of nationwide, representative diachronic research from 1988-1998-2005-2017, conducted among high school students (Mariański, 2018) and academic youth (Zaręba, Zarzecki, 2020). The leading subject matter of the studies on the student community focused on the religious and moral condition of adolescents, which also made it possible to look at values as its determinants. An important place is occupied by fundamental, sense-creating, ultimate and everyday life values. Janusz Mariański, a renowned researcher studying this subject matter emphasizes that affiliation and stabilization values remain at the highest position in the sphere of "the sacred" - touching the meaning of life. These include great love, happy family life, human trust and finding one's place in the society - individualistic 
goals and aspirations, centered around personal happiness attainable "here and now". The values that emphasize the modernization aspirations of the young generation of Poles - related to work, welfare, education or the pursuit of a chosen goal - have gained in importance. On the other hand, in the years 1988-2017, the rank of religious faith significantly decreased, both in the group of everyday values and, above all, solemn values, i.e. those for which life is worth sacrificing and which should be emphasized as important for the national group (Mariański 2018: 391-398 ).

Nationwide surveys of students, conducted according to the above discussed methodological principles, also show differences between the system of values and standards of pre-transformation youth of 1988 and 1989, and that of the young of 2005 and 2017. Sociologists draw attention to greater liberalism and openness to new experiences of modern students, compared to their predecessors, their tolerance, pragmatism, but also respect for the elderly and for the relationships with the nearest and dearest. The description of the Polish youth eludes dichotomous approaches, as they are modern and conservative at the same time, "like having fun, but think seriously about the future, participate in elections but do not like politics, or rather - politicians, "go to church" and believe in God [less than merely a few years ago - MS], but are critical of church teaching, especially on morality "(Korczyński, 2020: 83-84). On the other hand, “... the importance of religion in a young person's everyday life is certainly not disappearing, what is changing are merely the ways of experiencing the sacred sphere and the functions assigned to it by young people" (Wysocka, 2019, p. 118). In the socialization context, the emergence of diverse orientations, including those of active, creative young people repeatedly restructuring religiosity in consideration of their own biography (Pusztai, Demeter-Karászi, 2019) is a significant phenomenon.

These issues found their reflection in the research on academic youth in Poland, conducted during the pandemic in 2020 on a purposive sample of 621 respondents, using the on-line CAWI technique (Zaręba, Choczyński, 2020, pp. 157-172). The results reveal a high degree of altruism and empathy among students towards persons that are close to them, but this attitude is based on a subjectively interpreted moral imperative rather than on solid principles. One's conscience is the "authority" following which young people 
make choices and take binding decisions, whereas the Church is not perceived as an institutional authority. Young people still emphasize religion as one of the forms of their identification, with a vast majority admitting that they originate from backgrounds attached to the faith and religion, recognized as a part of an important cultural tradition. On the other hand, spirituality and contemplation of the meaning of life are of great importance to academic youth (Zaręba, Klimski, Sroczyńska, 2020). In the field of morality, the deeply rooted permissiveness of young people who accept various ethical attitudes (e.g. regarding sexuality) is revealed. In turn, the values most often emphasized are closeness and relationships with another person (friendship, love), as well as self-realization. The choices of young people - between the individualism of their own attitudes and the search of the presence of a close person or community reveal a transformational trait of identity and its references. This is also visible in the family sphere, which most often appears in the context of a conversation, intimacy and a sense of security (Kawińska, WróblewskaSkrzek, and Linek, 2020). The epidemic threat related to COVID-19 has not changed family ties so much, nor has it modified religious identity or spirituality. The issue that raises the greatest concerns of the participants of the study is the safety of close persons, which in turn is confirmed by the emerging "altruism within reasonable limits", accepted by young people and opposing purely utilitarian attitudes (Uklańska, Kotowska-Wójcik, Choczyński, 2020) . 
FINAL REMARKS - QUESTIONS ABOUT YOUNG PEOPLE AGAINST AN EMPIRICAL BACKGROUND ...

In the modern post-transformation world young Poles seem to be more resourceful in their everyday, social and emotional lives than their peers from the period of social transformation. However, neither their objectives nor action strategies (acting single-handedly) are conducive to organizing, Popular values and accompanying behaviors are frequently based on voluntary collaboration, being, however, free from existentially significant decisions and from taking responsibility. Although entering adulthood is delayed and accompanied by moratorium, the next stage means significant identity and social changes, which largely corresponds to the development of human capital, manifested in terms of skills, intuition and creative potential (Fairbanks, 2003). The importance of socialization environments can hardly be overestimated, by providing adolescents with various forms of resources: financial, material, institutional, related to knowledge and cultural capital, they create conditions for the strategy of developing prosperity. Majority of the youth accept the rules of the consumer society that do not favor the radicalization of activities in various areas of social life and generally lead to mild socialization within the existing structure. A certain part of them rebel, signaling problems falling within the area of social taboo (family model, abortion, in vitro, conception from rape, etc.), or the new spirituality related to ecology. On the other hand, young adults, aged 25-34, are at the stage of implementing individual life projects that adolescents only "sense". In Poland, the already mentioned "rational egoism" is becoming dominant, comprising economic activity, self-realization and the search for a balance between intimacy and professional work. The post-transformation period (post-accession, related to joining the EU) did not eliminate the deep "cultural rupture" associated with social inequalities, income differentiation and insufficient control over working conditions. On the one hand, the category of young, better educated, better-paid people who see better life prospects for themselves (mainly inhabitants of large cities) has grown, on the other - there is still a fairly large number of less well-off and less educated youth, from poorer social and cultural background, who have become marginalised by liberal modernization. The rupture is created 
by new political and party conflicts, breaking the old "post-Solidarity" and "post-communist" ties, which, combined with the geopolitical situation, still generates difficulties in predicting future changes in the values of Polish society (Jasińska-Kania 2012, pp. 336-339).

Regardless of the historical context, young people play the role of a certain "seismograph", and their attitudes and behaviors allow them to formulate conclusions (and ask questions) regarding the condition of the society in which they are growing up. It is interesting whether the ascending generations will manage to solve the "dilemma of three clocks" further stimulated by the pandemic. Will there be a change in values, attitudes and lifestyles in the near future, which will, on the one hand, guarantee a more even acceleration of modernization, and, on the other hand, maintain the continuity of generations, traditions and collective memory? 


\section{REFERENCES}

Bauman, Z.(2006). Liquid Fear. Cambridge: Polty Press. ISBN 978-07456-5450-8.

Bauman, Z. (2013). Ponowoczesność jako źródło cierpień. Warszawa: Wydawnictwo Sic! ISBN 978-83-619-6739-2.

Beck, U., Giddens, A., Lash, S. (1994). Reflexive Modernization. Politics, Tradition and Aesthetics in the Modern Social Order. Washington: Stanford University Press. Reprint. ISBN 978-08047-2472-2.

Brzozowska-Brywczyńska, M. (2019). Kulturowe środowisko jednorożców - kilka notatek o młodzieży i kulturze popularnej, in: K.Szafraniec (ed.), Młodzi 2018. Cywilizacyjne wyzwania. Edukacyjne konieczności (pp.203-209), Warszawa: A PROPOS. ISBN 978-83-942781-2-0.

Fairbanks, M. (2003). Zmiana mentalności narodu, czyli składniki procesu budowania dobrobytu, in: L.E. Harrison, S.P. Huntington (eds.), Kultura ma znaczenie. Jak wartości wpływaja na rozwój społeczeństw (pp.394-411). Trans.S.Dymczyk, Poznań: Zysk i S-ka Wydawnictwo. ISBN 83-7298-368-2.

Fukuyama ,F. (2006). The End of History and the Last Man. New York, London, Toronto, Sydney: Free Press. ISBN 978-0-02-910-975-5.

Gilejko, L. (2005), Społeczeństwo a gospodarka. Socjologia ekonomiczna. Warszawa: Wydawnictwo SGH. ISBN: 83-7378-154-4.

Grabowska, M., Gwiazda M. (eds.) (2019). Youth 2018. Warsaw: Public Opinion Research Center, National Bureau for Drug Prevention, pp.255.

Ingehart, R. (2003). Kultura a demokracja, in: L.E. Harrison, S.P. Huntington (eds.), Kultura ma znaczenie. Jak wartości wpływaja na rozwój społeczeństw (pp.146-168). Trans. S.Dymczyk, Poznań: Zysk i S-ka Wydawnictwo. ISBN 83-7298-368-2.

Jasińska-Kania, A. (2012). Zmiany wartości Polaków a procesy transformacji, europeizacji i globalizacji, in: A. Jasińska-Kania (ed.), Wartości i zmiany. Przemiany postaw Polaków w jednoczącej się Europie (pp.318-341), Warszawa: Wydawnictwo Naukowe SCHOLAR. ISBN 978-83-7383-488-0.

Kawińska, M., Wróblewska-Skrzek J., Linek A. (2020), Wolność wyboru czy przymus zwyczaju? Młodzież akademicka w dobie pandemii o związkach, intymności i więziach rodzinnych. Tom 1, Poznań: Wydawnictwo Rys. ISBN 978-83-66666-18-4.

Korczyński, T. M. (2020). Academic youth and their system of values, in: S.H. Zaręba, M. Zarzecki, (eds.), Between Construction and Deconstruction of the Universes of Meaning. Research into the Religiosity of Academic Youth in the Years 19881998-2005-2017 (pp.71-84), Berlin: Peter Lang. ISBN 978-3-631-79517-0.

Maffesoli, M. (2008), Czas plemion. Schyłek indywidualizmu w społeczeństwach ponowoczesnych. Trans. M. Bucholc. Warszawa: Wydawnictwo Naukowe PWN. ISBN 978-83-011-5566-7. 
Mariański, J. (2015), Wartość/wartości, in: J. Mariański (ed.), Leksykon socjologii moralności (pp.877-882), Kraków: ZW NOMOS. ISBN 978-83-7688-370-0.

Mariański, J. (2018), Kondycja religijna i moralna młodzieży szkół średnich $w$ latach 1988-1998-2005-2017 (raport z ogólnopolskich badań socjologicznych). Toruń: Wydawnictwo Adam Marszałek. ISBN 978-83-8019-919-4.

Niezgoda, M. (2014), Młodzież. Kłopotliwa kategoria socjologiczna. Jagiellońskie Studia Socjologiczne (1), ss. 13-34.

Nowak, S. (red.) (1989), Ciagłość i zmiana tradycji kulturowej. Warszawa: PWN. ISBN 83-01-06511-7.

Pusztai, G, Demeter-Karászi, Z. (2019). Analysis of Religious Socialization Based on Interviews Conducted with Young Adults. Religions 10 (6), 365. Retrieved (14.05.2021) from https://www.mdpi.com/2077-1444/10/6/365/htm. https://doi.org/10.3390/ rel10060365.

Smak-Wójcicka, M. (ed.) (2009). Opinions of Poles on Upbringing and the Roles of School in Educational Process. SR/121. Warsaw: Public Opinion Research Center, pp.15.

Sroczyńska, M. A. (2013). Rytuały w młodzieżowym świecie. Studium socjologiczne, Kraków: Wydawnictwo FALL. ISBN: 978-83-62275-40-3.

Sroczyńska, M. (2018). Rytuały jako praktyki pamięci zbiorowej (wybrane problemy transmisji pokoleniowej). Humanistyka i Przyrodoznawstwo 24, ss.211-227. ISSN: 1234-4087.

Sroczyńska, M. (2020). Młodzież w poszukiwaniu sacrum. Rozważania socjologiczne, Przegląd Religioznawczy. The Religious Studies Review 276 (2), ss.113-128. http:// doi.org/10.34813/ptr2.2020.8.

Such-Pyrgiel, M. (2012). System wartości osób żyjących w pojedynkę w świetle wyników badań własnych. Academic Journal of Sociology vol. 7/2012, pp.77-91.

Sułek, A. (1989), Wartości życiowe dwóch pokoleń, in: S. Nowak (ed.), Ciągłość i zmiana tradycji kukturowej (pp.293-313), Warszawa: PWN. ISBN 83-01-06511-7.

Szafraniec, K. (2012). Młodość jako wyłaniający się problem i nowa polityczna siła. Nauka (1), ss. 101-122. ISSN:1231-8515.

Szafraniec, K. (2019). Wprowadzenie. Dlaczego młodzi, dlaczego edukacja? in: K. Szafraniec (ed.), Młodzi 2018. Cywilizacyjne wyzwania, edukacyjne konieczności (pp.5-16), Warszawa: A PROPOS. ISBN 978-83-942781-2-0.

Szawiel, T. (2005). Młodzież polska i niemiecka: podstawowe wartości a przekonania i zachowania polityczne, in: K.Koseła i B.Jonda (eds.), Młodzi Polacy i młodzi Niemcy w nowej Europie (pp.191-247) Warszawa: Wydawnictwo IFiS PAN. ISBN 8373880909.

Szlendak, T. (2012). Zażyłość w oparach niezrozumienia. O hipotezie międzygeneracyjnej solidarności tolerancyjnej. Ruch Prawniczy, Ekonomiczny i Socjologiczny 74 (3), ss.75-90. https://doi.org/10.14746/rpeis.2012.74.3.4. 
Sztompka, P. (2005). Socjologia zmian społecznych, Kraków: Wydawnictwo Znak. ISBN 83-240-0598-7.

Uklańska, K., Kotowska-Wójcik O.A., Choczyński M. (2020). Wolność wyboru czy przymus zwyczaju. Młodzież akademicka $w$ dobie pandemii o sensie życia, relacjach i planach życiowych. Tom 3, Poznań: Wydawnictwo Rys. ISBN 978-83-66666-20-7. Wrzesień, W. (2015). Nie ma jednej młodzieży. Władza Sądzenia (7), ss. 21-25. ISSN 2300-1690.

Wysocka, E. (2019). Religijność młodzieży studenckiej-przypisywane religii znaczenia $w \dot{z} y c i u$ codziennym (dwie dekady zmian). Przegląd Religioznawczy.The Religious Studies Review 294 (4), ss.105-120. ISSN 1230-4379.

Zaręba, S.H., Zarzecki, M. (eds.), (2020). Between Construction and Deconstruction of the Universes of Meaning. Research into the Religiosity of Academic Youth in the Years 1988-1998-2005-2017. Berlin: Peter Lang. ISBN 978-3-631-79517-0.

Zaręba, S. H., Choczyński M. (2020). Rodzina i religia w czasie pandemii. Raport z ogólnopolskich badań socjologicznych PPPIW wśród młodzieży akademickiej w 2020 roku. Collectanea Theologica 90 (4), ss.157-172. http://doi.org/10.21697/ct.2020.90.4.07.

Zaręba, S. H., Klimski, W., Sroczyńska, M. (2020). Wolność wyboru czy przymus zwyczaju. Młodzież akademicka $w$ dobie pandemii o religii, duchowości i moralności. Tom 2, Poznań: Wydawnictwo Rys. ISBN 978-83-66666-19-1. 
